\title{
Whole-body cryostimulation application with age: a review
}

\author{
Sławomir Kujawski ${ }^{*}$, Julia L. Newton ${ }^{2}$, Karl J. Morten ${ }^{3}$, Pawel Zalewski ${ }^{1}$ \\ ${ }^{1}$ Department of Hygiene, Epidemiology, Ergonomy and Postgraduate Education, Division of
} Ergonomics and Exercise Physiology, Collegium Medicum in Bydgoszcz, Nicolaus Copernicus University, Toruń, Poland.

2. Population Health Science Institute, The Medical School, Newcastle University, Framlington Place, Newcastle-upon-Tyne, NE2 4HH, United Kingdom.

3. Nuffield Department of Women's and Reproductive Health, University of Oxford, Oxford, United Kingdom.

\section{* Correspondence:}

Sławomir Kujawski,

skujawski@cm.umk.pl

Permanent address: M. Curie Skłodowskiej 9 St, 85-094 Bydgoszcz

Keywords: Whole-body cryotherapy; cryostimulation; gerontology; older; cold; physical medicine

\begin{abstract}
In this review we examine studies exploring the effects of whole-body cryostimulation (WBC) from the perspective of applications with age with subjects over the age of 55 years old. Blood based
\end{abstract}


factors such as Erythropoietin and Il-3 increased in exercised trained and normal subjects after WBC while other parameters did not change. WBC treatment of patients with Rheumatoid Arthritis decreased levels of the inflammatory markers IL-6 and TNF- $\alpha$ with a in the elasticity of erythrocytes. In older subjects with Mild Cognitive Impairment (MCI) a significant improvement of short-term memory was noted with reduced levels of IL-6 with an increase in BDNF release when whole blood was challenged with $\mathrm{A} \beta 42$. WBC appears to be an exciting non-pharmacological treatments with pleiotropic action. It has potential in enhancing performance and alleviating chronic conditions in older subjects as part of an active rest programme in combination with regular physical exercise. In conditions associated with cognitive dysfunction including Alzheimer's and other forms of dementia the many properties of $\mathrm{WBC}$ as an affordable treatment has exciting therapeutic potential.

\section{$1 \quad$ Introduction}

'Cryostimulation' can be defined as cold exposure in a controlled manner for medical purposes, however it is not a completely uniform term: various methods have been used when considering procedures that involve the application of low temperatures. Before entering the final inner chamber, normally set at between $-100^{\circ} \mathrm{C}$ to $-130^{\circ} \mathrm{C}$ for clinical practice, subjects pass through one or two outer chamber. The outer chambers which adapt the patients to cold before entering the inner chamber are set at between $-30^{\circ} \mathrm{C}$ and $-60^{\circ} \mathrm{C}$. Subjects would be exposed for between 30 to 60 seconds in the outer chambers and up to 3 minutes in colder inner chamber. (Dębiec-Bąk, Skrzek, 2012).

In this review we focus on methods which provide cold exposure to the whole body. The term "cryotherapy" tends to be used for pathological conditions while "cryostimulation" is used to modulate the physiological aspects of aging. Published literature describing both acute and the longterm effects of a single exposure together with programs that include several exposures were 
analyzed. Physiological adaptation to cold exposure in therapeutic programs reveals the potential for the beneficial application of WBC in the field of age associated physiology and pathology.

\section{Materials and Methods}

\subsection{Literature search}

We carried out a systematic review of published articles on the application of cryotherapy in humans. Two investigators (SK and PZ) independently searched the PubMed database for all full-text articles on application of WBC on older people $>55$ years old. Searching databases was done on $12^{\mathrm{h}}$ February 2020.”. Using terms: whole-body[All Fields] AND ("cryotherapy"[MeSH Terms] OR "cryotherapy"[All Fields]) OR "cryostimulation"[All Fields] AND ("aged"[MeSH Terms] OR "aged"[All Fields] OR "elderly"[All Fields] OR "older"[All Fields]) AND "loattrfull text"[sb]. Duplicates were omitted during the analysis. Two co-authors (SK and PZ) independently reviewed each publication. All titles articles were analyzed and a full text to determine whether they could be included in the review. Discordant opinions were resolved through discussions with the participation of a third investigator (JN). Articles were excluded if (a) because of not being available in English, (b) examined group consisted of animal model, (c) studies in which cooling down was used as an perioperative technique, (d) manuscripts were not available in full text, (e) the WBC group examined mean age was below 55 based on previous reviews on effects of non-pharmacological treatment on older adults (Colcombe, Kramer, 2003; Silva et al., 2014). Because of relationship between middleaged populations functioning and the rate of functional decline in the next decades (Yamauchi et al., 1981; Hughes et al., 2018), it was decided to analyse study samples with mean age 55 years old to examine the effectiveness of WBC in healthy aging. 
Figure 1. Flow diagram of the process of selection of study materials

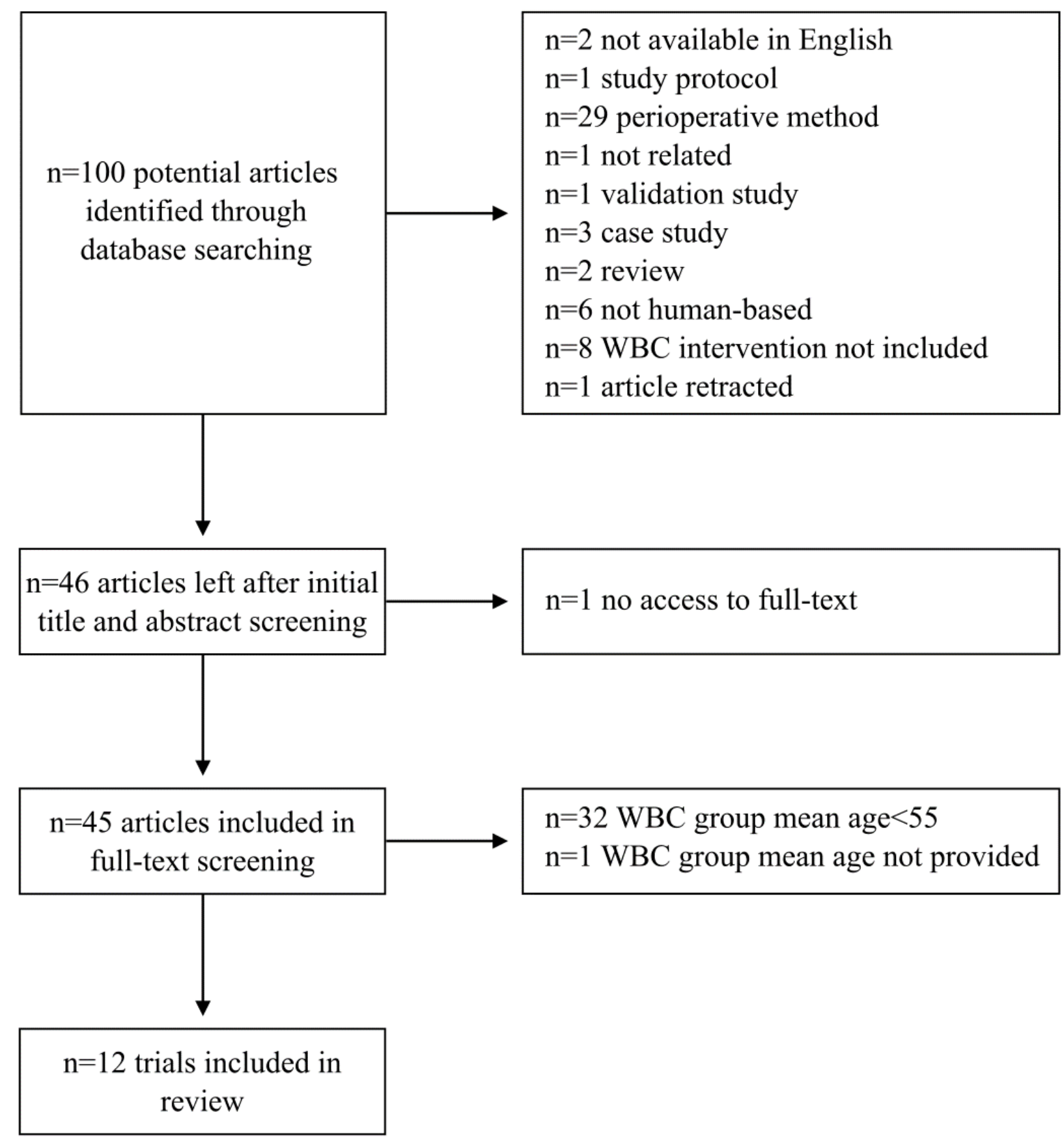

\subsection{Graphical presentation of results}

Cytoscape (version: 3.8.1) was used to create network graph presenting results of studies (Shannon et al., 2003). Size of circular nodes is proportionally related to sample size of WBC group in described 
study. Width of arrows is proportional to quantity WBC exposures in a study. Color of arrows indicates characteristic of observed effects.

\section{Discussion}

\subsection{WBC as performance enhancing technique in sport}

The effects of WBC on biochemical parameters in older amateur marathon runners vs a non-training group (Szymura et al., 2018) were examined. Increase in concentrations of erythropoietin (EPO) and interleukin-3 (IL-3) were observed seven days after completion of the WBC program in the marathon and in the non-training group. However no statistically significant effects on erythrocyte content and other physiological markers including bilirubin, haptoglobin, and extracellular hemoglobin (HGBecf) were observed in both groups.

\subsection{WBC application in patients group}

\subsubsection{WBC effectiveness in internal medicine}

Patients with Adhesive Capsulitis (AC) or frozen shoulder, associated with shoulder pain and stiffness underwent a WBC program (Ma et al., 2013). Statistically significant improvement in shoulder mobility, reduced pain intensity levels, as well as the ability to carry out every day activities were observed. The authors concluded that addition of WBC to standard physiotherapy is beneficial to decrease pain, improve the range of motion and the American Shoulder and Elbow Surgeons Standardized Shoulder Assessment Form score. Gizińska et al. showed the effectiveness of a rehabilitation program, including WBC in patients with Rheumatoid Arthritis (RA) (Gizińska et al., 2015). The study compared a traditional rehabilitation program to WBC on a cohort of patients with seropositive RA. Significant improvements in the severity of pain, duration of morning stiffness, disease activity score points in HAQ-DI after, fatigue, and walking time in 50-m test were noted in 
the WBC treated subjects. Moreover, decreases in the levels of IL- 6 and TNF- $\alpha$ were also noted. WBC also showed benefit in another autoimmune disorder helping women with lumbar spondylarthrosis a condition associated with irritation or compression of the nerve roots or the spinal cord (Kulis et al., 2017). Kulis et al. examined older women with lumbar spondyloarthrosis, who were randomly assigned into one of three 2-weeks treatment groups: WBC, kinesitherapy and both cryotherapy and kinesitherapy. WBC induce a decrease in the elasticity of erythrocytes (Kulis et al., 2017). Therefore, the immune-modulation effects of cryotherapy could be beneficial in several chronic, autoimmune diseases.

In study of Nugraha et al. effects of WBC on patients with chronic pain was examined. Control group consisted of sham WBC for 3 minutes at $-5^{\circ} \mathrm{C}$. Pain significantly decreased after sham WBC. Moreover, Pain Disability Index decreased significantly. Interestingly, the authors suggest that a program that consisted of ten exposures for 3 minutes at $-5^{\circ} \mathrm{C}$ could be sufficient stimuli in patients with chronic low back pain (Nugraha et al., 2015). In two studies on the effects of WBC in older men with chronic lower back pain significant benefits were also observed (Giemza et al 2014). The control group performed exercises alone while the WBC group combined exercise with WBC before training (Giemza et al., 2014). The group with additional WBC noted significantly lower values of active potentials of erector spinae muscles in the lumbar part of the spine and a significant increase in the range of the lumbar spine mobility. Pain levels also decreased with improvements in daily activities. A second longer study by Giemza et al. (2015) involved two groups: one with daily WBC exposures, whilst the second one consisted of exposures twice a week. Exposure in the main chamber lasted for three minutes. In the second group, significant improvements in range of motion, electromyography at rest, flexion and extension was noted. Pain decreased significantly. No significant improvement in activities of daily life was noted in neither group. 
In summary, it can be said that WBC is a procedure that is safe for older people and increase effectiveness of physiotherapy. However, lack of follow-up was underlined as the limitation of study. In the research of. Authors suggest that WBC is safe and effective in treating low back pain (Giemza et al., 2015).

\subsubsection{WBC effectiveness in nervous system disorders}

Rymaszewska et al. have reported for the first time the effects of WBC on cognitive function in 21 participants with mild cognitive impairment (MCI). Inclusion criterion was established as Montreal Cognitive Assessment score between 20 to 26 points, while patients with more and less points were excluded. Participants were assessed three times, before, after two weeks of WBC and after two weeks follow-up. A neuropsychological screening test used to diagnose mild cognitive impairment and early dementia-DemTect, Test Your Memory-TYM, the Saint Louis University Mental Status Examination-SLUMS, Verbal Fluency Test-FAS. Moreover, levels of IL-6, IL-8, IL-10, brainderived neurotrophic factor (BDNF) and NO were assessed. Following WBC a significant improvement in overall Demtect, SLUMS, FAS and TYM total scores were noted. Moreover, WBC increased plasma NO levels. When blood samples were challenged with A $\beta 42$ a significant reduction in levels of IL-6 and an increase in BDNF concentration was observed in WBC treated subjects. Authors suggested that this mechanism might be related to anti-inflammatory effect and complement activation of WBC. Moreover, increase in BDNF might lead to neurogenesis, what in turn potentially explains cognitive function improvement (Rymaszewska et al., 2018).

WBC programs have been applied in restless leg syndrome (RLS). In the WBC RLS group the quality of life index significantly improved and the Epworth sleepiness scale score significantly decreased. Periodic leg movements during sleep and wakefulness significantly improved. Disruption 
of sleep significantly decreased, while total sleep time increased. Significant improvements or disease symptoms and quality of life were observed in the $\mathrm{WBC}$ at $-60^{\circ} \mathrm{C}$ group solely compared to $10^{\circ} \mathrm{C}$ and local cryotherapy at $-17^{\circ} \mathrm{C}$ (Happe et al., 2016).

When used to treat Multiple Sclerosis patients with differing levels of fatigue WBC significantly improved scores in all the examined tests (Expanded Disability Status Scale, Multiple Sclerosis Impact Scale, Rivermead Motor Assessment: gross function, leg and trunk and arm and Fatigue Severity Scale). Interestingly larger levels of improvement were observed in the High compared to the Low fatigue group (Miller et al., 2016).

\subsection{WBC application safety concerns}

The standard dose of cold stress applied in WBC is one of the most extreme stimuli provided in the physical therapy field. In overall, effects of WBC on 55 patients with rheumatoid arthritis were examined. Authors noted an inadequate response in cortisol level changes in patients taking glucocorticoids (Straub et al., 2009) compared to group without such treatment.

In a study by Missmann 2016 research on patients with a spectrum of hypertension showed statistically significant increases in blood pressure after WBC in the all subjects and in the normotensive group measured before and after each exposure. During therapy which included 21 exposures, no significant change of blood pressure behavior was observed, except in normotensive subjects, who showed a wider range in their systolic BP values (Missmann et al., 2016). After WBC, increase of systolic BP in the group of subjects with pharmacologically treated arterial hypertension from $127.33 \pm 14.55$ to $133.28 \pm 15.36 \mathrm{mmHg}(\mathrm{p}=0.023)$ was noted. The diastolic increase in this group was from $80.47 \pm 8.81$ to $82.62 \pm 8.89 \mathrm{mmHg}(\mathrm{p}=0.034)$. In participants with mild arterial 
hypertension, but no medical treatment systolic BP increased from $129.71 \pm 12.34$ to $134 \pm 12.06$ mmHg (both p > 0.05) (Missmann et al., 2016).

Table 1. Summary of reviewed clinical trials. SD - standard deviation, IQR - interquartile range

\begin{tabular}{|c|c|c|c|c|}
\hline $\begin{array}{l}\text { The first } \\
\text { author, year }\end{array}$ & $\begin{array}{l}\text { WBC group N(mean } \\
\text { age } \pm \text { SD })\end{array}$ & $\begin{array}{l}\text { Number } \\
\text { of WBC } \\
\text { exposures }\end{array}$ & Method of cryotherapy & The main outcome \\
\hline Giemza, 2014 & $\begin{array}{l}\text { WBC group } \mathrm{n}=96 \\
\text { males, (mean age } 69.2 \text {, } \\
\text { range } 65-75 \text { ) with } \\
\text { chronic, lower back } \\
\text { pain > } 3 \text { months }\end{array}$ & 15 & $\begin{array}{l}\text { 3-week course of WBC } \\
\text { consisting of a } \\
\text { vestibule and main } \\
\text { chamber with } \\
\text { treatments lasting } 3 \\
\text { minutes. } 30 \text { seconds at } \\
\text { a temperature of }-60^{\circ} \mathrm{C} \\
\text { at vestibule. Next, the } \\
\text { subject moved to the } \\
\text { main chamber. At a } \\
\text { temperature of }-120^{\circ} \mathrm{C} \\
\text { for } 3 \text { minutes. After the } \\
\text { exposure, group } 1 \\
\text { moved to gym to }\end{array}$ & $\begin{array}{l}\text { Improvement in the } \\
\text { range of the lumbar } \\
\text { spine mobility and } \\
\text { lower values erector } \\
\text { spinae muscles } \\
\text { active potentials in } \\
\text { comparison in group } \\
1 \text { to the group } 2\end{array}$ \\
\hline
\end{tabular}




\begin{tabular}{|c|c|c|c|c|}
\hline & & & $\begin{array}{l}\text { therapeutic exercises } 5 \\
\text { days a week, } 45 \\
\text { minutes }\end{array}$ & \\
\hline Giemza, 2015 & $\begin{array}{l}\text { } \\
\text { WBC group } n=80 \\
\text { male, (mean age }= \\
70.1, \text { range } 65-77 \text { ) } \\
\text { with chronic, lower } \\
\text { back pain }>3 \text { months }\end{array}$ & 15 & $\begin{array}{l}3 \text { weeks treatment for } \\
\text { two groups. Group A } \\
\text { (n=40) consisted of } \\
\text { WBC exposures twice } \\
\text { a week. Group B (n = } \\
\text { 40) WBC exposures } 5 \\
\text { times per week. } \\
\text { Vestibule for } \\
\text { approximately } 30 \\
\text { seconds at a } \\
\text { temperature of }-60^{\circ} \mathrm{C} \\
\text { performed the same } \\
\text { to adopt to the cold. } \\
\text { temperature }-120^{\circ} \mathrm{C} \\
\text { mext, the subject } \\
\text { moved to the main }\end{array}$ & $\begin{array}{l}\text { Improvement in } \\
\text { lower back pain was } \\
\text { noticed group with } \\
\text { program consisting } \\
\text { of } 5 \text { exposures per } \\
\text { week }\end{array}$ \\
\hline
\end{tabular}




\begin{tabular}{|c|c|c|c|c|}
\hline & & & $\begin{array}{l}\text { therapeutic exercises } 5 \\
\text { days a week, } 45 \\
\text { minutes a day for a } \\
\text { period of } 3 \text { weeks }\end{array}$ & \\
\hline $\begin{array}{l}\text { Gizińska, } \\
2015\end{array}$ & $\begin{array}{l}\text { WBC group of patients } \\
\text { with RA } n=25 \text { (mean } \\
\text { age }=55.9, \mathrm{SD}=5.08 \\
\mathrm{IQR}=51-60)\end{array}$ & 10 & $\begin{array}{l}\text { 2-week rehabilitation } \\
\text { program for two } \\
\text { groups of patients with } \\
\text { Rheumatoid Arthritis. } \\
\text { WBC group ( } \mathrm{n}=25) \\
\text { received WBC } \\
\text { program (prechambers } \\
\left(-10^{\circ} \mathrm{C} \text { and }-60^{\circ} \mathrm{C}\right) \\
\text { into the main chamber } \\
\left(-110^{\circ} \mathrm{C}\right) \text {, for } 3 \text { min). } \\
\text { Traditional } \\
\text { rehabilitation group } \\
\text { (group II, } \mathrm{n}=19) \text { who } \\
\text { received a traditional } \\
\text { rehabilitation program } \\
\text { electrotherapy, }\end{array}$ & $\begin{array}{l}\text { Decrease in pain, } \\
\text { fatigue, interleukin } 6 \\
\text { and Tumor Necrosis } \\
\text { Factor. Improvement } \\
\text { in disease status, } \\
\text { functional } \\
\text { performance- was } \\
\text { observed in both } \\
\text { groups. Significant } \\
\text { improvement in } \\
\text { result of } \\
\text { questionnaire of } \\
\text { health assessment } \\
\text { was noted in group } \\
\text { II. }\end{array}$ \\
\hline
\end{tabular}




\begin{tabular}{|c|c|c|c|c|}
\hline & & & $\begin{array}{l}\text { ultrasound therapy, and } \\
\text { laser therapy. }\end{array}$ & \\
\hline Happe, 2016 & $\begin{array}{l}2 \mathrm{WBC} \text { group were } \\
\text { included }=12 \text { patients } \\
\text { with idiopathic restless } \\
\text { legs syndrome (mean } \\
\text { age }=56.9, \mathrm{SD}=16.1 \text { ) } \\
\text { in } \mathrm{WBC} \text { group at }-60^{\circ} \mathrm{C} \\
() . \mathrm{n}=11 \text { patients at } \\
\text { sham group at }-10^{\circ} \mathrm{C} \\
\text { (mean age }=61.6, \mathrm{SD}= \\
11)\end{array}$ & 10 & $\begin{array}{l}4 \text { weeks protocol } \\
\text { consisted of WBC for } \\
3 \text { minutes exposures } \\
\text { daily over two weeks, } \\
\text { followed by a four } \\
\text { week observation } \\
\text { period. Patients were } \\
\text { randomized into three } \\
\text { groups: cold air } \\
\text { chamber at }-60^{\circ} \mathrm{C}(\mathrm{n}= \\
12) ; \text { cold air chamber } \\
\text { at }-10^{\circ} \mathrm{C}(\mathrm{n}=12) ;\end{array}$ & $\begin{array}{l}\text { Improvements of } \\
\text { disease symptoms } \\
\text { and quality of life } \\
\text { were observed in the } \\
-60^{\circ} \mathrm{C} \text { group only. } \\
\text { Local cryotherapy } \\
\text { improved quality of } \\
\text { life and sleep quality } \\
\text { but not daytime } \\
\text { sleepiness or disease } \\
\text { symptoms. } \\
\text { Reduction in number } \\
\text { of wake phases per } \\
\text { night was observed } \\
\text { in the - } 10^{\circ} \mathrm{C} \text { group. }\end{array}$ \\
\hline
\end{tabular}




\begin{tabular}{|c|c|c|c|c|}
\hline Kulis, 2017 & $\begin{array}{l}\text { WBC group } \mathrm{n}=22 \\
\text { women with } \\
\text { spondyloarthrosis, } \\
\text { (mean age = } 66.6 \text { years, } \\
\text { inclusion criteria: } 65- \\
70 \text { ) }\end{array}$ & 10 & $\begin{array}{l}10 \text { WBC exposures: } \\
\text { pre-chamber for a } \\
\text { period of } 30 \text { seconds, } \\
\text { prechamber }-60^{\circ} \mathrm{C} \text { and } \\
\text { then cryochamber was } \\
-120^{\circ} \mathrm{C} \text {. Kinesitherapy, } \\
\text { involved active } \\
\text { exercises to strengthen } \\
\text { the muscles of the } \\
\text { back, abdomen and } \\
\text { limbs, balance and } \\
\text { breathing exercises } \\
\text { each bout lasted for } 40 \\
\text { minutes in total }\end{array}$ & $\begin{array}{l}\text { Decrease in the } \\
\text { indices of } \\
\text { erythrocyte elasticity } \\
\text { and aggregation was } \\
\text { noted in women after } \\
\text { combined therapy } \\
\text { consisting of WBC } \\
\text { and kinesitherapy. }\end{array}$ \\
\hline Miller, 2016 & $\begin{array}{l}\text { MS patients with } \\
\text { chronic fatigue were } \\
\text { divided into high } \\
\text { fatigue group } \mathrm{n}=24, \\
\text { (mean age }=55.6, \mathrm{SD}= \\
4.2 \text { ), low fatigue group, } \\
\mathrm{n}=24,(\mathrm{mean} \text { age }= \\
55.7, \mathrm{SD}=3.2 \text { ) }\end{array}$ & 10 & $\begin{array}{l}10 \text { WBC exposures, } \\
\text { one exposure each day. } \\
\text { The vestibule with a } \\
\text { temperature of }-60^{\circ} \mathrm{C} \\
\text { and the main chamber - } \\
110 \text { to }-160^{\circ} \mathrm{C} \text { for } 2-3 \\
\text { min }\end{array}$ & $\begin{array}{l}\text { Improvement in } \\
\text { highly fatigued } \\
\text { patients }\end{array}$ \\
\hline
\end{tabular}




\begin{tabular}{|c|c|c|c|c|}
\hline $\begin{array}{l}\text { Missmann, } \\
2016\end{array}$ & $\begin{array}{l}\text { Subjects with } \\
\text { rheumatic disorders } \\
\text { and elevated BP where } \\
\text { divided into based on } \\
\text { history of disease: } \\
\text { pharmacologically } \\
\text { treated hypertension } \\
\text { group n }=5 \text { (mean age } \\
=61.2, \text { SD }=7.6 \text { ) and } \\
\text { untreated hypertension } \\
n=5(\text { mean age }=56.4, \\
\text { SD }=9.1) \text { ), age range } \\
35-69\end{array}$ & 21 & $\begin{array}{l}21 \text { exposures of } \mathrm{WBC} \\
\text { consisted of } \\
\text { temperature of }-15^{\circ} \mathrm{C} \text {, } \\
\text { followed by a room } \\
\text { with }-60^{\circ} \mathrm{C} \text {, and the } \\
\text { main room with }-110^{\circ} \mathrm{C} \\
\text { for approximately } 3 \\
\text { min }\end{array}$ & $\begin{array}{l}\text { Increase of blood } \\
\text { pressure after WBC } \\
\text { was found in the } \\
\text { whole sample and in } \\
\text { the normotensive } \\
\text { group }\end{array}$ \\
\hline Nugraha, 2015 & $\begin{array}{l}\mathrm{n}=29 \text { sham-WBC } \\
\text { degree (mean age }= \\
55.1, \mathrm{SD}=7.19) \text { with } \\
\text { chronic low back pain, } \\
\text { age range } 18-65\end{array}$ & 10 & $\begin{array}{l}10 \text { exposures on } \mathrm{WBC} \\
\text { at }-67^{\circ} \mathrm{C} \text { degree and } \\
\text { sham-WBC at }-5^{\circ} \mathrm{C} \\
\text { degree }\end{array}$ & $\begin{array}{l}\text { No difference } \\
\text { between groups in } \\
\text { terms of } \\
\text { effectiveness, } \\
\text { therefore authors } \\
\text { suggest that }-5^{\circ} \mathrm{C} \\
\text { degree could be } \\
\text { sufficient stimuli in } \\
\text { that group of patients }\end{array}$ \\
\hline
\end{tabular}




\begin{tabular}{|c|c|c|c|c|}
\hline $\begin{array}{l}\text { Rymaszewska, } \\
2018\end{array}$ & $\begin{array}{l}\text { WBC group } \mathrm{n}=21 \\
\text { participants with Mild } \\
\text { Cognitive Impairment } \\
(\mathrm{MCI})(\text { mean age }= \\
65.38, \mathrm{SD}=7.2)\end{array}$ & 10 & $10 \mathrm{WBC}$ exposures & $\begin{array}{l}\text { Improved cognitive } \\
\text { function, inter alia, } \\
\text { performance in a } \\
\text { several memory } \\
\text { tests, significant } \\
\text { increase of Nitric } \\
\text { Oxide and Brain- } \\
\text { derived neurotrophic } \\
\text { factor and reduction } \\
\text { of interleukin } 6 .\end{array}$ \\
\hline Ma, 2013 & $\begin{array}{l}\text { WBC group } \mathrm{n}=15 \\
\text { patients with AC of the } \\
\text { shoulder (mean age = } \\
56.1, \mathrm{SD}=6.3 \text { ), all } \\
\text { patients }(\mathrm{n}=30 \text { ) age } \\
\text { range } 47 \text { to } 66\end{array}$ & 12 & $\begin{array}{l}30 \text { subjects were } \\
\text { randomly assigned to } \\
\text { either the WBC group } \\
\text { (n=15) or the non- } \\
\text { WBC group (n=15). } \\
\text { The WBC group } \\
\text { received physical } \\
\text { therapy modalities, } \\
\text { passive joint } \\
\text { mobilization, and } \\
\text { WBC, whereas the } \\
\text { non-WBC group } \\
\text { received only physical }\end{array}$ & $\begin{array}{l}\text { Both treatments } \\
\text { improved range of } \\
\text { motion, pain, and } \\
\text { shoulder function } \\
\text { Addition of WBC to } \\
\text { standard therapy was } \\
\text { more effective in } \\
\text { terms of } \\
\text { improvement of } \\
\text { pain, range, and the } \\
\text { results of } \\
\text { questionnaire on } \\
\text { functional limitation }\end{array}$ \\
\hline
\end{tabular}




\begin{tabular}{|c|c|c|c|c|}
\hline & & & 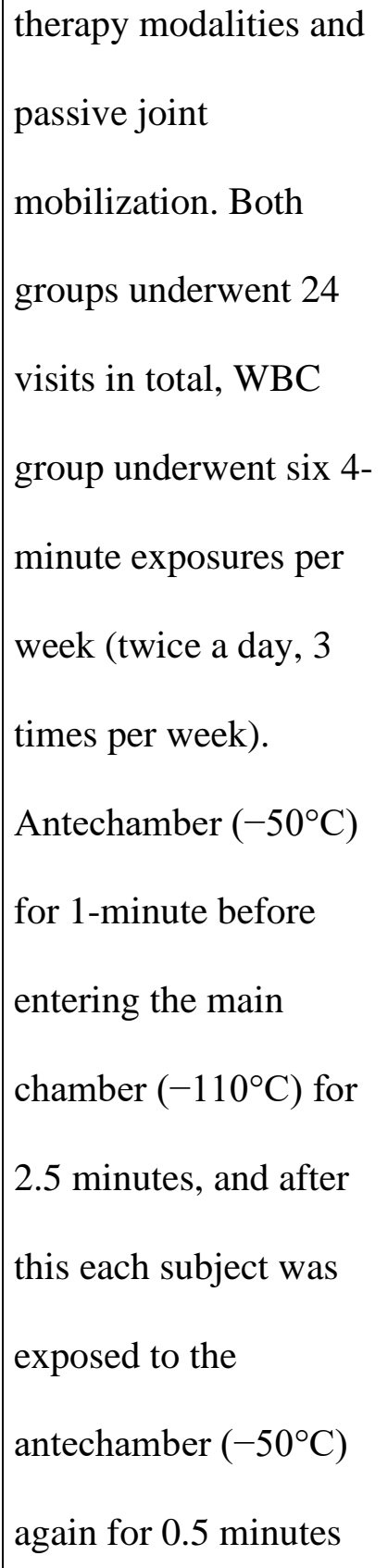 & $\begin{array}{l}\text { and pain of the } \\
\text { shoulder. }\end{array}$ \\
\hline . & $\begin{array}{l}\text { WBC group of patients } \\
\text { with RA with } \\
\text { glucocorticoids mean } \\
\text { age }<55 \text { were exposed } \\
\text { on } \mathrm{WBC} \text { at } 60^{\circ} \mathrm{C},(\mathrm{n}=\end{array}$ & 20 & $\begin{array}{l}7 \text { days therapy, (WBC } \\
\text { at }-60^{\circ} \mathrm{C} \text { (for } 2 \mathrm{~min} \text {, } \\
\text { group 2) applied } 3 \\
\text { times per day }\end{array}$ & $\begin{array}{l}\text { In overall, in patients } \\
\text { with glucocorticoids } \\
\text { an inadequate cold } \\
\text { stress response was } \\
\text { noted }\end{array}$ \\
\hline
\end{tabular}




\begin{tabular}{|c|c|c|c|c|}
\hline & $\begin{array}{l}12, \text { mean age }=55.7 \\
\mathrm{SD}=2.4\end{array}$ & & & \\
\hline $\begin{array}{l}\text { Szymura, } \\
2018\end{array}$ & $\begin{array}{l}\mathrm{n}=10 \text { amateur } \\
\text { marathon runners } \\
\text { (mean age }=55.9, \mathrm{SD}= \\
5.51) . \text { The nontraining } \\
\text { group consisted of } 10 \\
\text { men leading a } \\
\text { sedentary lifestyle } \\
\text { (mean age = } 62, \mathrm{SD}= \\
5.75), \text { all participants } \\
\text { age ranged } 50-70\end{array}$ & 24 & $\begin{array}{l}24 \mathrm{WBC} \text { treatments } \\
\text { over a period of } 8 \\
\text { weeks, } 30 \mathrm{~s} \text { in the } \\
\text { vestibule at }-60^{\circ} \mathrm{C} \text {. } \\
\text { Main chamber, at - } \\
130^{\circ} \mathrm{C} \text { for } 3 \mathrm{~min} .\end{array}$ & $\begin{array}{l}7 \text { days after the } \\
\text { completion of WBC } \\
\text { program an increase } \\
\text { in concentrations of } \\
\text { EPO and } \\
\text { interleukin3 was } \\
\text { noted. No effects on } \\
\text { erythrocyte content } \\
\text { and indicators, } \\
\text { bilirubin, } \\
\text { haptoglobin, and } \\
\text { extracellular } \\
\text { hemoglobin levels } \\
\text { were observed in } \\
\text { both groups of } \\
\text { marathon runners. }\end{array}$ \\
\hline
\end{tabular}


Network included in figure 2 presents result noted in the WBC groups included in the described studies. Size of circular nodes is proportionally related to sample size of group which underwent WBC. In total, $n=338$ subjects underwent WBC. Number of WBC exposures is proportional to width of arrows. Color of arrows indicates study conclusions: green arrows are related to beneficial effects of WBC. Yellow arrows denote studies, which observed WBC effects that might potentially limit WBC application or enforce WBC protocol adjustment in some older people with comorbidities. However, further studies on comparison of effects of different WBC protocols in patients groups are needed.

Figure 2. Effects of WBC application with age in described studies

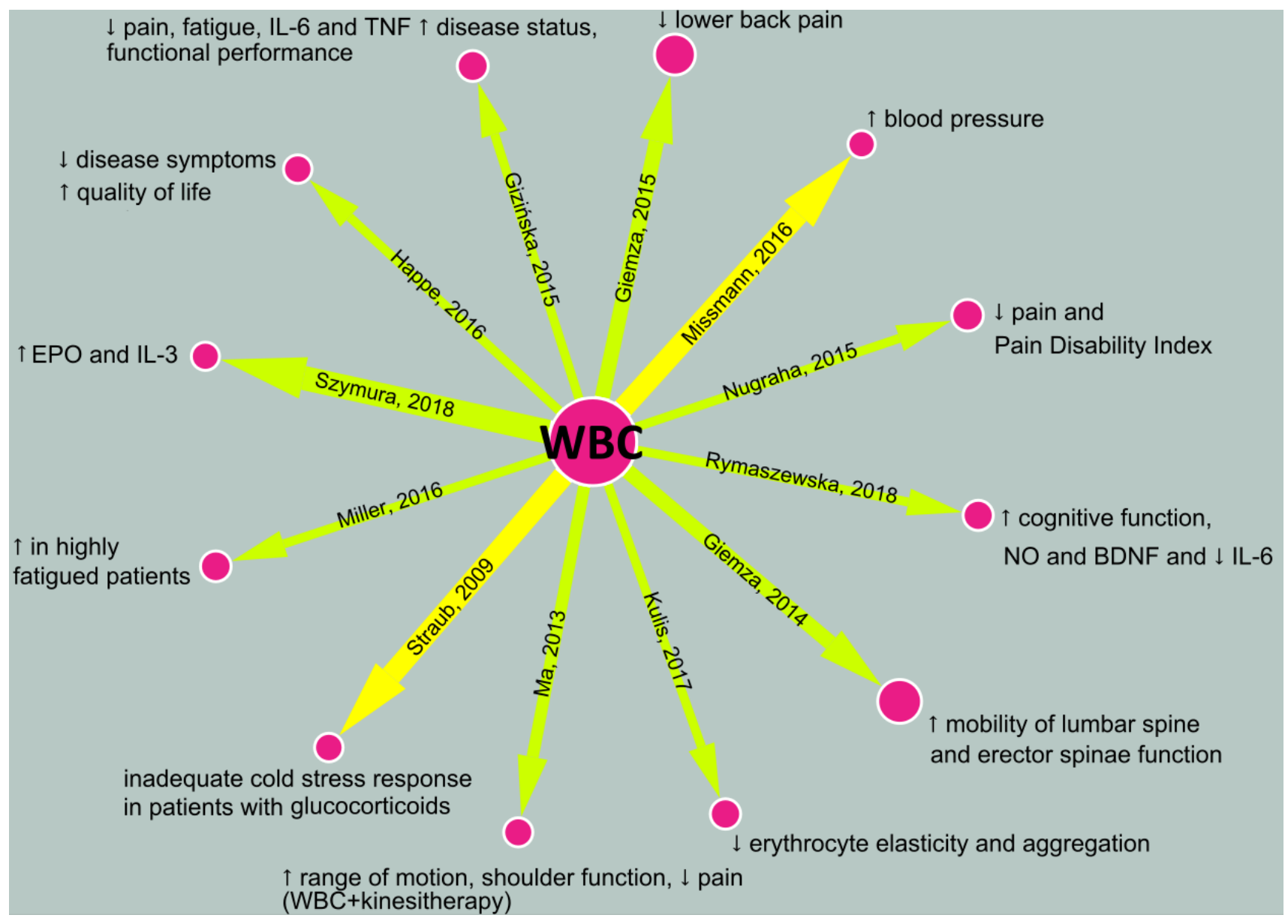


Legend: WBC - whole-body cryostimulation, IL-6 - Interleukin 6, TNF - Tumor necrosis factor, NO Nitric Oxide, BDNF - Brain-derived neurotrophic factor, EPO-erythropoietin, IL-3 -Interleukin 3

Risk of bias assessments for analysed studies is presented in Figure 3. None seems to be free of potential risk of bias. In overall, quality of analysed studies in the above review are poor due to the lack of control group, randomization and blinding procedure.

Figure 3. Presentation of risk of bias assessments for analysed studies 


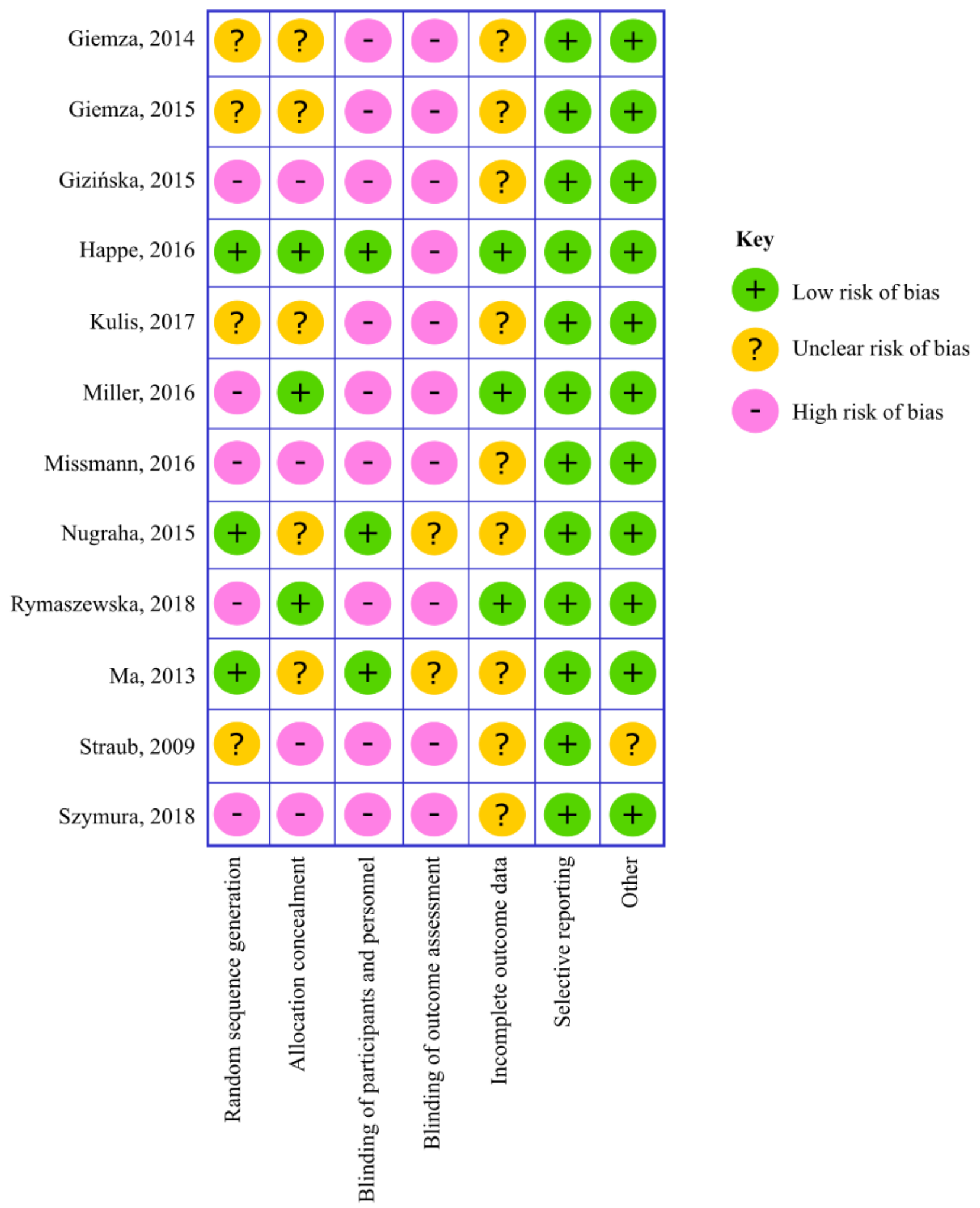

\subsection{Caveats and limitations}


As a limited number of studies of WBC in older cohorts have been carried out with different methods and approaches we cannot determine if that WBC has a clear beneficial effect. In an attempt to improve methodological consistency we excluded studies based on only one WBC exposure. All of the reviewed research protocols therefore consisted of a set of cryotherapy exposures in the form of a program. This is important as it has been shown that during repeated severe whole-body cold stress of short duration, thermal sensation and comfort become enhanced potentially due to an adaptive response during the first exposures (Smolander et al., 2004). Therefore, it is important to distinguish both the acute effects of single exposures of cryotherapy, as well as the delayed effects of a cryotherapy program on aspects of sports performance and if any potentially detrimental effects when studying functional effects in the older population.

Literature search in the above review was based only on one database, which might be a potential limitation. Moreover, cut off of examined samples which was set on mean age of 55 years, might limit the ability of generalization of the findings of this review to older people population.

Another potential bias could come from differences in the populations examined. Amateur marathon runners and non-training (Szymura et al., 2018), participants with MCI (Rymaszewska et al., 2018) patients with AC of the shoulder (Ma et al., 2013) patients with seropositive Rheumatoid Arthritis (Gizińska et al., 2015; Missmann et al., 2016) women with lumbar spondyloarthrosis (Kulis et al., 2017) chronic low back pain (Nugraha et al., 2015; Giemza et al., 2014; Giemza et al., 2015), patients with glucocorticoids (Straub et al., 2009), patients with Adhesive Capsulitis (Szymura et al., 2018), patients with idiopathic restless legs syndrome (Happe et al., 2016), Multiple Sclerosis patients (Miller et al., 2016) may not reflect the ailments of an aging populations.

The populations examined were heterogenous in terms of age and there might be possible age differences regarding the effects of WBC. Therefore, the potential limitation of the above review is 
the lack of description of WBC effects in research where the participants mean age is lower than 55 years old. Analysis of WBC effects with age as its mediator should be done in further studies. The general safety of the therapy in the oldest age groups, and the combination of effects on chronic inflammatory and neurodegenerative diseases, which can be a specific focus for treatments in older age groups, should be examined in the further studies.

\section{Conflict of Interest}

The authors declare that the research was conducted in the absence of any commercial or financial relationships that could be construed as a potential conflict of interest.

\section{Author Contributions}

SK and PZ contributed to conception and design of the work; literature search, data collection and analysis; drafting, writing, and critical review of the text. JLN contributed to conception and design of the work; data collection and analysis; drafting, writing, and critical review of final document; figure design and drawing. KJM contributed to conception and design of the work; drafting, and critical review of the text.

\section{Funding}

Nicolaus Copernicus University in Toruń, Poland has funded publications costs of the above manuscript.

\section{Acknowledgments}

Not applicable

\section{References}


Colcombe, S., \& Kramer, A. F. (2003). Fitness effects on the cognitive function of older adults: a meta-analytic study. Psychological science, 14(2), 125-130. https://doi.org/10.1111/1467-9280.t01-1$\underline{01430 .}$

Dębiec-Bąk, A., \& Skrzek, A. (2012). Porównanie rozkładu temperatury powierzchniowej ciała kobiet i mężczyzn za pomocą termowizji. Acta Bio-Optica et Informatica Medica. Inżynieria Biomedyczna, 18(1), 25-30.

Giemza, C., Matczak-Giemza, M., De Nardi, M., Ostrowska, B., \& Czech, P. (2015). Effect of frequent WBC treatments on the back pain therapy in elderly men. The Aging Male, 18(3), 135-142.

Giemza, C., Matczak-Giemza, M., Ostrowska, B., Bieć, E., \& Doliński, M. (2014). Effect of cryotherapy on the lumbar spine in elderly men with back pain. The Aging Male, 17(3), 183-188. https://doi.org/10.3109/13685538.2013.863860.

Gizińska, M., Rutkowski, R., Romanowski, W., Lewandowski, J., \& Straburzyńska-Lupa, A. (2015). Effects of whole-body cryotherapy in comparison with other physical modalities used with kinesitherapy in rheumatoid arthritis. BioMed research international, 2015. https://doi.org/10.1155/2015/409174.

Happe, S., Evers, S., Thiedemann, C., Bunten, S., \& Siegert, R. (2016). Whole body and local cryotherapy in restless legs syndrome: A randomized, single-blind, controlled parallel group pilot study. Journal of the neurological sciences, 370, 7-12. https://doi.org/10.1016/j.jns.2016.09.006.

Hughes, M. L., Agrigoroaei, S., Jeon, M., Bruzzese, M., and Lachman, M. E. (2018). Change in cognitive performance from midlife into old age: Findings from the Midlife in the United States (MIDUS) study. Journal of the International Neuropsychological Society, 24(8), 805-820. https://doi.org/10.1017/s1355617718000887 
Kulis, A., Misiorek, A., Marchewka, J., Głodzik, J., Teległów, A., Dąbrowski, Z., and Marchewka, A. (2017). Effect of whole-body cryotherapy on the rheological parameters of blood in older women with spondyloarthrosis. Clinical Hemorheology and Microcirculation, 66(3), 187-195. https://doi.org/10.3233/ch-160230.

Ma, S. Y., Je, H. D., Jeong, J. H., Kim, H. Y., and Kim, H. D. (2013). Effects of whole-body cryotherapy in the management of adhesive capsulitis of the shoulder. Archives of Physical Medicine and Rehabilitation, 94(1), 9-16. https://doi.org/10.1016/j.apmr.2012.07.013.

Miller, E., Kostka, J., Włodarczyk, T., \& Dugue, B. (2016). Whole-body cryostimulation (cryotherapy) provides benefits for fatigue and functional status in multiple sclerosis patients. A case-control study. Acta Neurologica Scandinavica, 134(6), 420-426.

Missmann, M., Himsl, M., Mur, E., Ulmer, H., \& Marschang, P. (2016). Impact of Whole Body Cryotherapy at $-110^{\circ} \mathrm{C}$ on Subjects with Arterial Hypertension. Archivum immunologiae et therapiae experimentalis, 64(1), 75-82. https://doi.org/10.1007/s00005-015-0363-9

Nugraha, B., Gunther, J. T., Rawert, H., Siegert, R., \& Gutenbrunner, C. (2015). Effects of whole body cryo-chamber therapy on pain in patients with chronic low back pain: a prospective double blind randomised controlled trial. Eur J Phys Rehabil Med, 51(2), 143-8.

Rymaszewska, J., Urbańska, K. M., Szcześniak, D., Stańczykiewicz, B., Trypka, E., \& Zabłocka, A. (2018). The improvement of memory deficits after whole-body cryotherapy-the first report. CryoLetters, 39(3), 190-195.

Shannon, P., Markiel, A., Ozier, O., Baliga, N. S., Wang, J. T., Ramage, D., Amin, N., Schwikowski, B \& Ideker, T. (2003). Cytoscape: a software environment for integrated models of biomolecular interaction networks. Genome research, 13(11), 2498-2504. 
Silva, N. L., Oliveira, R. B., Fleck, S. J., Leon, A. C., \& Farinatti, P. (2014). Influence of strength training variables on strength gains in adults over 55 years-old: a meta-analysis of dose-response relationships. Journal of Science and Medicine in Sport, 17(3), 337-344.

https://doi.org/10.1016/j.jsams.2013.05.009.

Smolander, J., Mikkelsson, M., Oksa, J., Westerlund, T., Leppäluoto, J., \& Huttunen, P. (2004).

Thermal sensation and comfort in women exposed repeatedly to whole-body cryotherapy and winter swimming in ice-cold water. Physiology \& behavior, 82(4), 691-695.

https://doi.org/10.1016/j.physbeh.2004.06.007.

Straub, R. H., Pongratz, G., Hirvonen, H., Pohjolainen, T., Mikkelsson, M., \& Leirisalo-Repo, M. (2009). Acute cold stress in rheumatoid arthritis inadequately activates stress responses and induces an increase of interleukin 6. Annals of the rheumatic diseases, 68(4), 572-578.

https://doi.org/10.1136/ard.2008.089458

Szymura, J., Wiecek, M., Maciejczyk, M., Gradek, J., Kantorowicz, M., \& Szygula, Z. (2018).

Unchanged erythrocyte profile after exposure to cryogenic temperatures in elder marathon runners. Frontiers in Physiology, 9, 659. https://doi.org/10.3389/fphys.2018.00659.

Yamauchi, T., Kim, S., \& Nogami, S. (1981). Extreme cold treatment (-150 ${ }^{\circ}$ ) on the whole body in Rheumatoid Arthritis. X Europaischer Kongreß für Rheumatologie. Abstractband, 1054.

\section{Data Availability Statement}

Not applicable 